\title{
вмJ Global Health How to improve outbreak response: a case study of integrated outbreak analytics from Ebola in Eastern Democratic Republic of the Congo
}

To cite: Carter SE,

Ahuka-Mundeke S,

Pfaffmann Zambruni J, et al.

How to improve outbreak response: a case study of integrated outbreak analytics from Ebola in Eastern Democratic Republic of the Congo. BMJ Global Health 2021;6:e006736. doi:10.1136/ bmjgh-2021-006736

Handling editor Seye Abimbola

Received 25 June 2021 Accepted 3 August 2021

Check for updates

C Author(s) (or their employer(s)) 2021. Re-use permitted under CC BY-NC. No commercial re-use. See rights and permissions. Published by BMJ.

For numbered affiliations see end of article.

Correspondence to

Simone E Carter;

SCARTER@UNICEF.ORG

\section{ABSTRACT}

The emerging field of outbreak analytics calls attention to the need for data from multiple sources to inform evidence-based decision making in managing infectious diseases outbreaks. To date, these approaches have not systematically integrated evidence from social and behavioural sciences. During the 2018-2020 Ebola outbreak in Eastern Democratic Republic of the Congo, an innovative solution to systematic and timely generation of integrated and actionable social science evidence emerged in the form of the Cellulle d'Analyse en Sciences Sociales (Social Sciences Analytics Cell) (CASS), a social science analytical cell. CASS worked closely with data scientists and epidemiologists operating under the Epidemiological Cell to produce integrated outbreak analytics (IOA), where quantitative epidemiological analyses were complemented by behavioural field studies and social science analyses to help better explain and understand drivers and barriers to outbreak dynamics. The primary activity of the CASS was to conduct operational social science analyses that were useful to decision makers. This included ensuring that research questions were relevant, driven by epidemiological data from the field, that research could be conducted rapidly (ie, often within days), that findings were regularly and systematically presented to partners and that recommendations were co-developed with response actors. The implementation of the recommendations based on CASS analytics was also monitored over time, to measure their impact on response operations. This practice paper presents the CASS logic model, developed through a field-based externally led consultation, and documents key factors contributing to the usefulness and adaption of CASS and IOA to guide replication for future outbreaks.

\section{INTRODUCTION}

The 2018-2020 Ebola outbreak in Eastern Democratic Republic of the Congo (DRC) was the second largest in recorded history. ${ }^{1} \mathrm{By}$
Summary box

During the 2018-2020 Ebola outbreak in Eastern Democratic Republic of the Congo, an innovative solution to systematic and timely generation of integrated and actionable social science evidence emerged in the form of the Cellulle d'Analyse en Sciences Sociales (CASS)

- The CASS worked closely with data scientists and epidemiologists operating under the Epidemiological Cell to produce integrated outbreak analytics (IOA).

- IOA is a transdisciplinary approach where quantitative epidemiological analyses, health services and systems data, behavioural field studies, social science analyses, contextual data (eg, socioeconomic population data) and operational programmes data are analysed holistically to help better explain and understand drivers and barriers to outbreak dynamics.

- The CASS conducted rapid, operational social science analyses to complement epidemiological health services and programmes data which were analysed in an integrated manner and were systematically presented and used to inform response activities and strategies.

- The implementation of the recommendations based on CASS analytics was monitored over time, to measure the use of evidence and its impact on response operations.

the time the outbreak was declared over on 25 June 2020, there had been 3481 confirmed cases, including 2299 fatalities, in an area affected by a protracted crisis due to long standing political tensions and conflicts, and widespread historic mistrust in government and public authority. ${ }^{2}$ The DRC is a country at high risk of epidemics; at the time of the 
10th Ebola outbreak, the Eastern region experienced concurrent epidemics of polio, cholera, measles and plague. ${ }^{34}$ Coordinating an Ebola response in this challenging context required decision makers to have situational awareness of multiple aspects of a dynamic and fast-paced public health crisis from which to make timely strategic and operational decisions. ${ }^{56}$

The emerging field of outbreak analytics calls attention to the need for data from multiple sources to inform evidence-informed decision making in managing infectious diseases outbreaks. ${ }^{78}$ To date, these approaches have not systematically integrated evidence from social and behavioural sciences as a core part of integrated outbreak analytics (IOA).$^{9}$ During the 2018-2020 Ebola outbreak, an innovative solution to systematic and timely generation of integrated and actionable social science evidence emerged in the form of the Cellulle d'Analyse en Sciences Sociales (CASS), a social science analytics cell. CASS was embedded within the national response structure and worked closely with data scientists and epidemiologists operating under the Epidemiological Cell to produce IOA, where quantitative epidemiological analyses were complemented by behavioural field studies and social science analyses to help better explain and understand drivers and barriers to outbreak dynamics. CASS delivered 58 integrated studies, which led to 112 evidence-informed recommendations co-developed with response pillars to improve and adapt response interventions and strategies.

This paper details the operational processes of the CASS based on an extensive review of CASS documents and tools, strategies and reports and a 2-week externally led consultation (NG University of Oxford), funded by the Wellcome Trust and UK Foreign, Commonwealth and Development Office. This consultation included interviews with 79 stakeholders from different levels of the Ebola outbreak response in the DRC to understand their views on key characteristics of the CASS model, usefulness and challenges as well as aspects that could be improved and what would be needed to replicate the model for future outbreaks. The outcome of this consultation led to refinements in how CASS achieved its outcomes and impact, and informed subsequent CASS support in the DRC to COVID-19, cholera, the 11th and 12th Ebola outbreaks as well as to the Ebola outbreak in Guinea (April 2021)..$^{10-12}$

\section{THE ORIGINS OF CASS}

The CASS developed organically and in response to needs expressed by response actors to better understand the determinants of epidemiological trends, transmission dynamics and differences across affected communities, from a holistic epidemiological, social and behavioural perspective. The studies which led to a more formal set up of CASS started in October 2018, with a UNICEFdeployed social epidemiologist (SEC). In October 2018, SEC conducted a qualitative study to better understand the situation for pregnant and lactating women who were not eligible for the vaccine and not reported by vaccination or surveillance teams. This first study directly supported response pillars including psychosocial, surveillance, vaccination and epidemiological teams to better integrate those non-eligible for the vaccine. In November 2018, Medair, an Ebola healthcare provider, requested support to better understand reasons for nonreporting or referral of suspected Ebola cases in one of their supported healthcare facilities. ${ }^{13}$ This request led to the first CASS partnership study, a qualitative study with healthcare workers and community members to better understand barriers to healthcare access. SEC led this study and provided training for Medair staff to lead future groups. In January 2019, partnerships continued to expand and included working with the Infection Prevention and Control-Water Sanitation Hygiene (IPC-WASH) pillar and WHO IPC teams to conduct studies to better understand perceptions and use of healthcare facilities and IPC measures and again, this reinforced a multiactor approach to the collection and use of data. The CASS was able to rapidly provide evidence and understanding that was relevant and adapted, responding to critical questions. The inclusion of a broad range of response actors, including government and non-government organisations within the CASS studies, reinforced relationships with the end line data users, contributing to CASS credibility and trust.

\section{OPERATIONALISATION OF THE CASS DURING THE EBOLA OUTBREAK}

CASS was set up as an operational analytics service embedded within the national Ebola response structure. Figure 1 presents a programme logic model that sets out core activities of the service, together with their short-term, medium-term and long-term outcomes. Programme inputs were also defined to guide planning for future replication of this initiative.

\section{Inputs}

Key human and financial resource inputs

A retrospective review of the CASS allowed for identifying the resources necessary to replicate the experience in future outbreaks and public health crises. This included detailing the human resources (multidisciplinary skillset, mix of national and international staff, levels of seniority, job descriptions, etc), physical resources (office space, research resources, etc), financial resources (budget estimates per study, budget estimates for staff posts and by location, etc), standard operating procedures, communications (advocacy documents, branding, etc) and tools for delivering analytics and building capacity of the CASS teams.

\section{Key strategic inputs}

Key features related to the success of the CASS were identified. These included (1) the importance of senior leadership endorsement of the approach, (2) the practical 


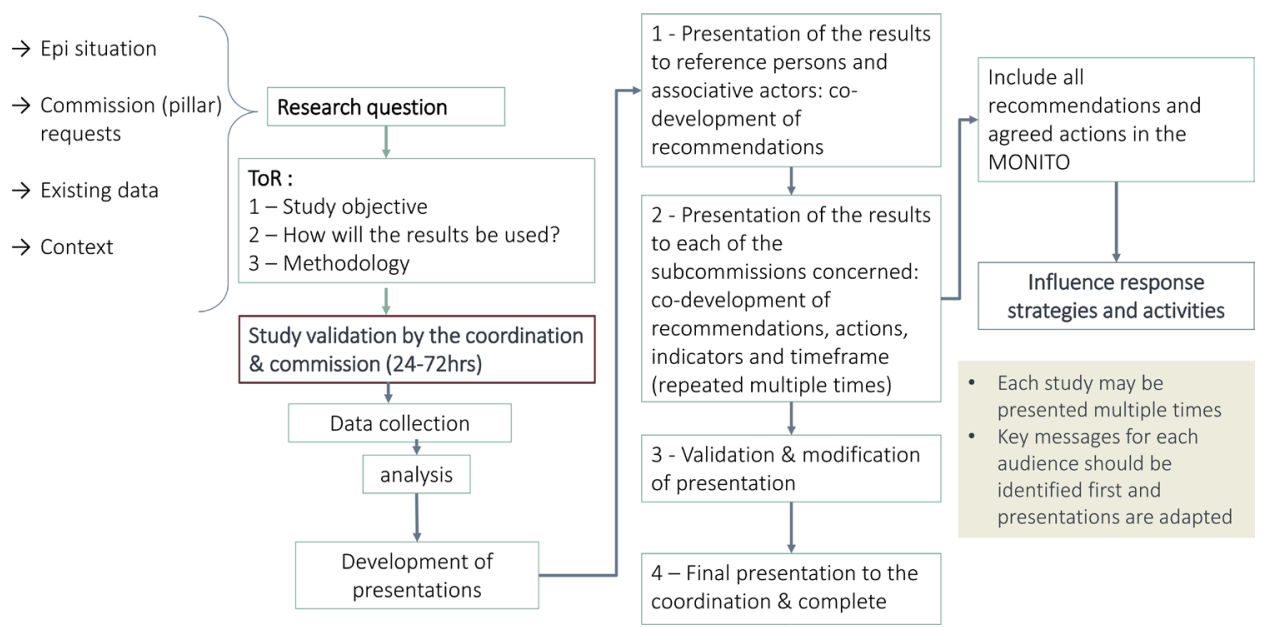

Figure 1 Flow of Cellulle d'Analyse en Sciences Sociales analytics process.

translation and use of evidence in coordination meetings, (3) the strategic positioning of the unit, alongside the Epidemiological Cell and under the coordination and (4) physical presence at both field and response coordination level of the response, to ensure the operational relevance of key questions addressed by the CASS and that both epidemiological and sociobehavioural approaches to those could be addressed in concert. The CASS team maintained a full-time presence at (local) subcoordination-level meetings. This built trust and familiarity with the CASS and reinforced the interest of multiple stakeholders in the response to request and use CASS evidence. Subcoordination, locally based CASS teams routinely presented localised data and evidence, facilitating the co-development of recommendations and uptake of evidence-based decision-making. The strategic positioning of the CASS both at subcoordination and coordination level helped engage with local response actors and decision makers, and ensured that the evidence could be presented to multiple audiences and response pillars (figure 2).

\section{Activities}

Conducting operational social science research

The primary activity of the CASS was to conduct operational social science analyses to orient decision-making (see table 1 for examples of CASS studies). CASS research questions were prioritised in collaboration with partners and Ministry of Health (MoH) local-level and nationallevel leadership as a response to critical unknowns or as a complement to epidemiological analyses. Analyses from the CASS provided critical evidence on factors influencing outbreak dynamics and intervention uptake by location, specific groups and over time. CASS studies were rapidly conducted, taking 3-15 days from idea development to

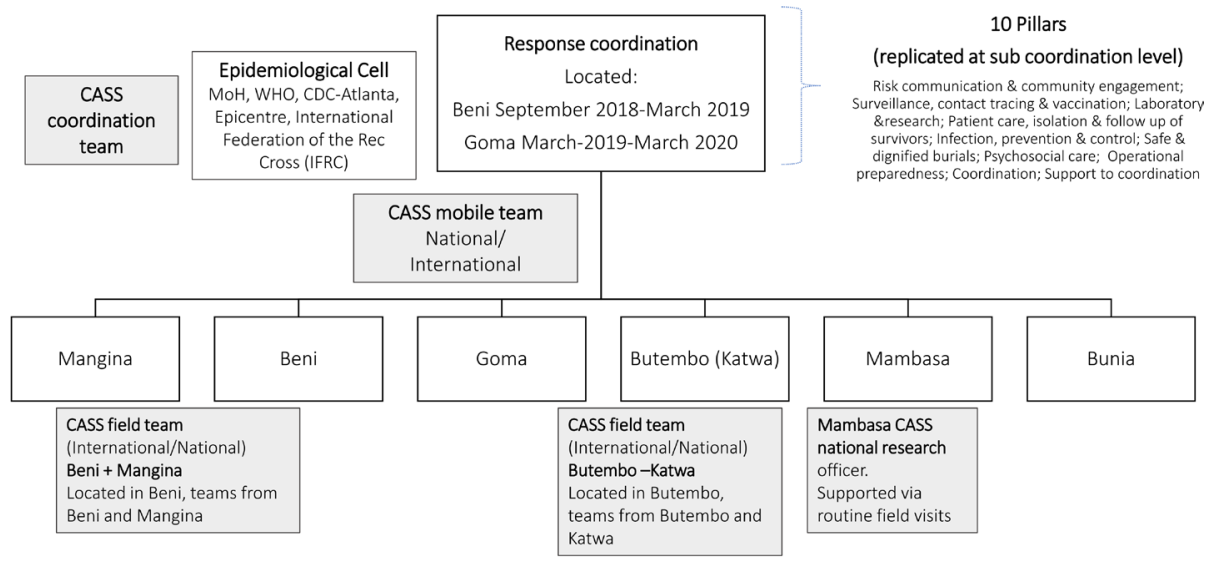

The CASS team had full time capacity to cover 3 subcoordinations and their surrounding areas. These were the most recurrent hotspots.

Rapid studies conducted in Goma and Bunia were done by the mobile team

NB: the sub-coordination locations changed during the outbreak based on case-load

Figure 2 Structure and placement of Cellulle d'Analyse en Sciences Sociales (CASS) teams across the coordination and subcoordination structure of the Ebola response. ${ }^{13}$ The CASS team had full time capacity to cover three subcoordinations and their surrounding areas. These were the most recurrent hostpots. Rapid studies conducted in Goma and Bunia were done by the mobile team. Note: the subcoordination locations changed during the outbreak based on case-load. MoH, Ministry of Health. 
Table 1 Additional examples of changes and impact of the use of CASS studies during the 2018-2020 Eastern Democratic Republic of the Congo Ebola outbreak

Study and methods

1 Perceptions of risk among pregnant and breastfeeding women

(October 2018) ${ }^{18}$
Rationale: routinely collected surveillance data on uptake of the novel Ebola vaccine did not include information on pregnant or breastfeeding women as they were not considered eligible for vaccination at that time Key partner: MoH, UNICEF, surveillance pillar, psychosocial pillar

Study aim: to understand views of pregnant and breastfeeding women who had been identified as contacts (self-reported) and their partners in relation to accessing the novel Ebola vaccine Methods: rapid qualitative study
Results/Recommendations

- Women who were not eligible for the vaccine reported feeling abandoned, not receiving psychosocial support or surveillance and follow-up (compared with their neighbours or others who had been contacts). Both women and men requested that women be allowed the vaccine, regardless of the risks to the pregnancy as the vaccine was being promoted as the best way to save one's life.

- Female breastfeeding healthcare workers continued to work and place themselves at risk, without access to the vaccine, while others decided independently to stop breast feeding (or report stopping) to access the vaccine.

Change and impact on outbreak

intervention

1. Surveillance forms were adapted to include pregnant and breastfeeding status.

2. Vaccination teams began reporting daily how many non-eligible were not vaccinated: this further highlighted the daily number of women at risk because of the eligibility criteria.

3. Kits were provided to support breastfeeding mothers (healthcare worker, frontline responder, highrisk contact) who wished to stop breast feeding and access the vaccine.

4. Advocacy to allow pregnant and breastfeeding women access to the novel Ebola vaccine. This was raised to SAGE and, following this, the policy was changed in June 2019.

2 Perceptions of infection prevention control (IPC) and healthcare services measures (January 2019) $^{19}$
Rationale: low uptake of recommended IPC decontamination practices among local communities

Key partner: $\mathrm{MoH}$, IPC pillar, WHO

Study aim: to understand local community views on IPC decontamination practices in order to inform community engagement and improve practice

Methods: qualitative interviews and focus group discussions

Understanding delays in
treatment- seeking
$($ July 2019)
transmission ${ }^{21}$
Rationale: epidemiological data highlighted continued long delays in treatment- seeking (5-12 days), increasing the risk of mortality of those affected by Ebola

Key partner: MoH, Epidemiology Cell, CDCAtlanta

Study aim: to explain the potential causes in delays related to treatment-seeking among those with symptoms of Ebola

Methods: meta- analysis of existing qualitative and quantitative data form CASS studies

Rationale: epidemiological analysis indicated that, when a nosocomial transmission occurred, there was a greater likelihood of further spread

Key partner: IPC-WASH pillar

Study aim: to explain potential reasons and factors related to nosocomial infection Methods: integrated analysis including a meta-synthesis of healthcare worker surveys, household surveys and qualitative studies on healthcare-seeking behaviour integrated with epidemiological analysis of transmission chains, DHIS2 data and programmes data from IPC teams
Community members saw the value and benefit of decontamination practices. Reluctance to engage with decontamination practices was linked to the fact that decontamination for Ebola was being undertaken by unknown external teams in a context of significant mistrust. For other infectious disease scenarios requiring decontamination, local community members were used to this being conducted at the level of the health facilities by local healthcare workers.
Barriers to treatment-seeking were largely due to misunderstanding of Ebola symptoms (posters and images focused on severe rather than more common symptoms) as well as fear that Ebola Treatment Centres would result in death.

. Guidelines for community engagement in IPC (March 2019).

2. Training of 95 local hygienists in 30 neighbourhoods in all the health areas of Beni and 50 others in the health facilities of 15 surrounding health facilities (July 2019).

3. Recommendation implemented and inserted in the strategic response plan 4: involve communities and families in decontamination and in close collaboration with the risk communication and community engagement and psychosocial support (PSS) teams.

1. Development of new communications tools (messages and images) which include 'dry' symptoms and make comparisons to other known illnesses (now included in all communication tools).

2. Messages and campaigns focused on early treatment-seeking for survival.

IPC data highlighted that less than half of the healthcare facilities had received training.

- CASS healthcare worker surveys conducted across all response locations smaller and harder to reach facilities were less likely to report having received support.

- The majority of healthcare workers were not being trained on location and did not feel able to stop nosocomial transmission due to reported lack of training.

- Many healthcare workers did not feel able to detect a possible Ebola case.

- Healthcare workers reported increased community tensions and fear of accusations from communities for working for the response, which may influence willingness to raise an alert.

- Traditional practitioners were reported as not sufficiently involved in the response.
New IPC-WASH training to focus on smaller healthcare facilities and to include practical demonstrations and application as a key component of the training.

2. Communication materials adapted to better explain and communicate on common Ebola systems (less visibly severe).

3. Traditional practitioners were included into the IPC-WASH pillars across multiple locations, reinforcing their engagement with the response. 


\begin{tabular}{|c|c|c|c|c|}
\hline & Study & $\begin{array}{l}\text { Rationale for study, key partners, study aim } \\
\text { and methods }\end{array}$ & Results/Recommendations & $\begin{array}{l}\text { Change and impact on outbreak } \\
\text { intervention }\end{array}$ \\
\hline 5 & $\begin{array}{l}\text { Factors of risk for children } \\
\text { under } 5 \text { years of age } \\
\text { (multiple studies Octobers } \\
\text { 2018, December 2019, } \\
\text { March 2020) }\end{array}$ & $\begin{array}{l}\text { Rationale: children under } 5 \text { years of age } \\
\text { continued to represent } 14 \% \text { of caseloads } \\
\text { throughout the outbreak; however, limited } \\
\text { understanding of the factors contributing } \\
\text { to a greater exposure and infection than } \\
\text { anticipated. } \\
\text { Key partner: Epidemiology Cell } \\
\text { Study aim: understand the factors (situation, } \\
\text { behaviours, services use) recurrent among } \\
\text { children under } 5 \text { years of age and drivers } \\
\text { influencing risk and transmission among small } \\
\text { children } \\
\text { Methods: integrated analysis using illness } \\
\text { narratives and verbal autopsies, DHIS2 } \\
\text { analysis (interrupted time series), transmission } \\
\text { chain analysis, programmes data (IPC data), } \\
\text { household and healthcare worker surveys, } \\
\text { epidemiological analysis, no delays in } \\
\text { treatment-seeking, symptoms and health } \\
\text { outcomes for children under } 5 \text { years of age }\end{array}$ & $\begin{array}{l}\text { CASS analysis of health services } \\
\text { use data demonstrated increased } \\
\text { use of healthcare facilities by up } \\
\text { to } 300 \%-400 \% \text { for children under } \\
5 \text { years of age. } \\
\text { IPC data highlighted that } \\
\text { nosocomial infections were } \\
\text { more likely in smaller healthcare } \\
\text { facilities; there the increased use } \\
\text { of services was likely to cause } \\
\text { overcrowding and limited capacity } \\
\text { to stop nosocomial transmission. } \\
\text { Surveillance data found that } \\
\text { children under } 5 \text { years of age } \\
\text { were less to be listed as contacts } \\
\text { and, when listed, less likely to be } \\
\text { followed up. } \\
\text { CASS qualitative data found that } \\
\text { children continued to receive } \\
\text { injections and intravenous } \\
\text { treatments in healthcare facilities, } \\
\text { that parents reported bed-sharing } \\
\text { and lack of IPC measures. Parents } \\
\text { and surveillance teams also } \\
\text { perceived small children as not } \\
\text { likely to be contacts and were } \\
\text { therefore not quick to list them. }\end{array}$ & $\begin{array}{l}\text { 1. Communication materials were } \\
\text { developed to explain the risks } \\
\text { for children (when they may } \\
\text { have become a contact) and the } \\
\text { importance of listing children. } \\
\text { 2. Training for PSS and surveillance } \\
\text { teams were reinforced to increase } \\
\text { the number of children under } 5 \\
\text { years of age listed as contacts and } \\
\text { to reinforce follow-up of cases. }\end{array}$ \\
\hline
\end{tabular}

This list is not exhaustive. A complete list of CASS studies conducted during the outbreak can be found online. ${ }^{23}$

; CASS, Cellulle d'Analyse en Sciences Sociales; CDC, Centers for Disease Control and Prevention; DHIS2, The District Health Information Software (https://dhis2.org/); IPC-WASH, Infection Prevention and Control-Water Sanitation Hygiene; MoH, Ministry of Health.

study outputs depending on the question and methodology applied (see figure 1 for the CASS process).

Each CASS study had terms of reference (ToR) endorsed by the response leadership. As a result, $\mathrm{MoH}$ and response partners had some ownership of the process and in turn, could influence the uptake of recommendations based on evidence. When a study theme was identified, the CASS team would develop the ToR and rapid tools within 24-48 hours and ensure relevant approvals with local and national leadership. ToRs were rapidly approved because the analyses were requested and required to guide response interventions, and due to the close working relationships, which were established over time between the full-time field-based CASS teams, the $\mathrm{MoH}$ and response actors. On average, data collection was conducted over 2-6 days. Local research teams collected data in local languages. Pairs of local researchers (one asking and discussing, the second taking notes and supporting to probe on questions) collected qualitative data. Participants provided informed consent verbally, however these were not audio recorded as, in agreement with local research teams, this was often perceived as intrusive, especially in a context where distrust of the Ebola response was high. Quantitative studies required, on average, 5-7 days for data collection.

In-country CASS teams, with periodic support from the US Centers for Disease Control and Prevention (CDC-Atlanta) social and behavioural sciences teams, conducted analyses over the course of 5-10 days, using Atlas-ti (qualitative data) and Epi Info or SPSS (quantitative data). CASS team leads analysed qualitative studies at field locations and validated by local researchers validated these analyses prior to these being presented to partners. Data analysis to presentation took between 48 hours and 7 days, depending on the study and data collected.

\section{Team structure, coordination and capacity building}

The CASS team consisted of local, national and international members. Local and national staff were key to the CASS's ability to rapidly conduct studies. These researchers were familiar with local culture, community and language and were able to rapidly build trust and respectfully gain access to households as well as to healthcare facilities and staff. The CASS local research teams were operational across the four main subcoordination areas at all time. The consistency and presence of local, permanent CASS teams at each subcoordination meant that relationships were built with the subcoordination MoH leadership as well as pillars and implementing partners. The CASS field teams actively participated in daily response meetings and presented findings on a weekly basis adapted for different audiences. A key CASS priority was to reinforce the operational research capacity of the Congolese teams. Weekly trainings of the local research teams were organised to improve their analytical skills (including qualitative and quantitative research methodology), as well as their ability to communicate results and to build relationships with stakeholders and reinforce the use of data. At the end of the outbreak, the local research teams were supported to build a small network among themselves for future, localised and evidence-based programmes and response. 
Ensuring a collaborative ethos and facilitating platform

A keysuccess of the CASS was the collaborative ethos and open sharing of all tools, studies and results. This way of working provided a shared space to link research leadership, implementing partners and donors. Although hosted, supported and championed by UNICEF, the CASS was promoted as a service for all response partners in its organisation and ownership of results. ${ }^{14}$ The CASS also sought humanitarian and government partners to contribute to its activities via data sharing or human resources, for example, via sharing healthcare facility data from partners such as Medair, data collection support from IRC and deployment of surge capacity from CDC-Atlanta and MSF-Epicentre. Hence, the CASS provided a platform to bring various actors together in order to support transdisciplinary analytics and led to the unique opportunity to bridge the gap between the worlds of field research and humanitarian practice. CASS presentations also ensured that response actors remained up-to-date with understanding of the outbreak dynamics and changes to response interventions and strategies based on evidence, creating a space for exchange and collaboration. The CASS ethos was perceived to encourage an open discourse on challenges and successes which helped to identify gaps (in analytics and interventions) and ensured evidence-based decision making for the outbreak responders (see table 1). ${ }^{14}$ The CASS used the space to obtain feedback and adapted its analyses to meet partner requests.

\section{Knowledge mobilisation}

CASS routinely presented evidence on a weekly basis at coordination and subcoordination levels. Formats of the presentation included slide deck and short briefs narrative which presented adapted and easy to understand evidence summaries for the specific audience with links to the full studies. The in-country participants in presentations and recipients of briefs included civil society organisations, local $\mathrm{MoH}$, national and international non-government organisations (NGOs), strategic government leadership and donors. The presentations targeted different audiences through adapted presentations and ensured that the evidence collected was being used to inform ongoing and planned interventions. The inclusion of national-level and local-level response actors and communities was regarded as very positive to ensure co-ownership and to improve support of the interventions to contain the outbreak. Examples of local-level inclusion included ${ }^{1}$ the presentation of results directly to the local-level health leadership who participated in healthcare worker studies ${ }^{2}$; presenting to local NGOs made up of community members who could contribute to the co-development of recommendations ${ }^{3}$; returning to specific women's associations to share and present on how evidence was being used (based on their study contributions) and ${ }^{4}$ via local researchers who, from the communities, would share back results among youth and other associations.

Co-development and monitoring recommendations

Each CASS study aimed to provide evidence that could lead to concrete, operational action for strengthening the
Ebola response. Subcoordination pillars or implementing partners (local actors representing community members) co-developed recommendations after each presentation of the results. The results presented by the CASS, when appropriate, included specific community-based recommendations that had been collected. See table 1 for examples of how evidence from CASS analytics impacted the outbreak response. To ensure that the evidence was being used, between June and August 2019, the CASS and the $\mathrm{MoH}$, organised a series of workshops with pillars and response actors to identify preferences for the development and monitoring of evidence-based recommendations. Following this process, the CASS developed a tool (MONITO), available online, to track and follow implementation of the co-developed recommendations. Recommendations and actions were tracked by study, by location and by pillar or actor. ${ }^{15} \mathrm{CASS}$ local research teams in each subcoordination were responsible for following up recommendations and collecting documentation to demonstrate its application. CASS presented regular updates on progress against recommendations based on the MONITO. The bilateral exchanges and discussions with pillars supported implementation of the co-developed recommendations. MONITO highlights the use of CASS analyses to inform response interventions and the impact of using integrated social sciences evidence in outbreak response. Over the 23 months of the outbreak, the CASS was able to track 112 recommendations that were adopted and followed up using the MONITO. At the end of the outbreak, $86 \%$ of recommendations had been completely (63\%) or partially (23\%) implemented.

\section{Short-term, medium-term and long-term outcomes of CASS activities}

The overarching long-term goal of the CASS was to contribute to a swift end to the Ebola outbreak by integrating epidemiological analyses with evidence on social and behavioural perspectives and drivers to better understand outbreak dynamics and inform response strategies and activities. Several short-term and medium-term outcomes identified as part of the consultations are presented in the programme logic model (see figure 3). Key immediate outcomes of CASS activities include the rapid production of systematic, operational, ethical and trustworthy evidence based on the needs of the response and targeted, tailored action-oriented recommendations to inform response activities. The collaborative ethos of CASS operations was key to build trust among partners and achieve its success. In this way, the CASS became institutionalised as part of the response and gained legitimacy. This legitimacy enabled the CASS to influence change at local and strategic levels. Recommendations were more likely to be seen as credible and relevant and to be acted on. CASS recognition within UNICEF, WHO and the $\mathrm{MoH}$, and participation in the strategy planning, was perceived as critical for its credibility. The participatory partnership with the $\mathrm{MoH}$ and the Epidemiological Cell led also to an exchange of expertise and improved 


\begin{tabular}{|c|c|c|c|c|}
\hline Inputs & CASS activity & Immediate outcome & Short term outcome & Longer term outcome \\
\hline $\begin{array}{l}\text { Human resources } \\
\text { Skill mix, core competencies to } \\
\text { include } \\
\text { - Leaders trained in both } \\
\text { epidemiology and social } \\
\text { sciences } \\
\text { - Information Manager with } \\
\text { data management skills in } \\
\text { epidemiological, programme } \\
\text { and social sciences data } \\
\text { Analysts specializing in } \\
\text { epidemiological data, in } \\
\text { programmes data, in health } \\
\text { services (DHIS2) data and } \\
\text { social sciences (qualitative) } \\
\text { data } \\
\text { Local researchers (speaking } \\
\text { language, known and trusted } \\
\text { by communities) }\end{array}$ & $\begin{array}{l}\text { Operational Analytics } \\
\text { - } \quad \text { Questions arise from epidemiologic data or } \\
\text { implementation challenges; inquiry is coordinated } \\
\text { with Epidemiology Cell methodology driven by the } \\
\text { questions sought to answer (e.g. type of information } \\
\text { needed, qualitative, quantitative, mixed methods, } \\
\text { anthropological approaches) } \\
\text { - } \quad \text { Data collected using local teams, depending on } \\
\text { - } \text { method. } \\
\text { bow are data managed, stored, shared following } \\
\text { - } \quad \text { Data analysed and interpreted rapidly with a focus } \\
\text { on addressing operational needs, while maintaining } \\
\text { objectivity, and openness. } \\
\text { Results are shared within the response actors at } \\
\text { local levels (Pillars, NGOs, local health actors) first, } \\
\text { then with national coordination. } \\
\text { - } \text { Research ethics includes only collecting data when } \\
\text { necessary, assuring the entire team understands and } \\
\text { - } \text { practices respect for individuals' privacy and } \\
\text { autonomy } \\
\text { Data access and sharing: the data is made available } \\
\text { to everyone in the response. } \\
\text { beyond response }\end{array}$ & $\begin{array}{l}\text { Systematic, ethical, } \\
\text { reproducible research } \\
\text { conducted - rigorous } \\
\text { and transparent } \\
\text { methods }\end{array}$ & $\begin{array}{l}\text { CASS accepted as part } \\
\text { of response - } \\
\text { institutionalized, } \\
\text { accepted as integral } \\
\text { part of holistic } \\
\text { response - legitimacy } \\
\text { Useful and useable } \\
\text { research à } \\
\text { trustworthy evidence } \\
\text { for decision making in } \\
\text { the response } \\
\text { Change - local level } \\
\text { and strategic } \\
\text { The complementarily } \\
\text { of research and } \\
\text { response activity can } \\
\text { be exploited to } \\
\text { provide more efficient } \\
\text { and effective evidence } \\
\text { for decision making. } \\
\text { Recommendations } \\
\text { more likely to be } \\
\text { enacted -- specific, } \\
\text { tailored to need and } \\
\text { make sense to } \\
\text { response teams. }\end{array}$ & $\begin{array}{l}\text { Response is informed } \\
\text { by evidence - more } \\
\text { effective response a } \\
\text { quicker end to the } \\
\text { outbreak. } \\
\text { Greater appreciation } \\
\text { within the response } \\
\text { structure for the need } \\
\text { to understand } \\
\text { community } \\
\text { perspectives and to } \\
\text { obtain authentic } \\
\text { community } \\
\text { participation in } \\
\text { decision-making for } \\
\text { emergency response } \\
\text { measures. }\end{array}$ \\
\hline
\end{tabular}

\begin{tabular}{|c|c|c|c|c|}
\hline $\begin{array}{l}\text { Strategic positioning } \\
\text { - Sit at strategic level, } \\
\text { independent of response } \\
\text { pillars } \\
\text { Senior leadership endorsement } \\
\text { Standard Operating Procedures } \\
\text { - Review and align } \\
\text { Toolbox for research methods and } \\
\text { capacity building } \\
\text { Communication and branding } \\
\text { No specific visibility or } \\
\text { branding linked to one } \\
\text { organisation (e.g. colours } \\
\text { neutral) }\end{array}$ & \multicolumn{2}{|c|}{$\begin{array}{l}\text { Recommendations } \\
\text { - } \quad \text { Recommendations are developed in collaboration } \\
\text { with local response leadership after results are } \\
\text { presented. By consensus. } \\
\text { - How they are tracked } \\
\text { - MONITO } \\
\text { Capacity building } \\
\text { - } \quad \text { Systematic, documented over time } \\
\text { - } \quad \text { Based on specific studies or learning in real-time }\end{array}$} & $\begin{array}{l}\text { National/ local staff } \\
\text { have research } \\
\text { capacity }\end{array}$ & \\
\hline \multicolumn{5}{|c|}{ Dynamic, system level influences } \\
\hline \multicolumn{2}{|c|}{$\begin{array}{l}\text { Contextual factors that re-enforce or promote CASS } \\
\text { Nature of the outbreak: protracted, research innovation key feature } \\
\text { - CASS position in response ecosystem: complementarity with other innovative } \\
\text { initiatives e.g. IFRC feedback, epi cell } \\
\text { - Culture of co-operation among NGOs - relationship driven - start of outbreak } \\
\text { - } \quad \text { Consistency of leadership staff over protracted crisis }\end{array}$} & \multicolumn{3}{|c|}{$\begin{array}{l}\text { Contextual factors that undermined or threaten } \\
\text { - Recruitment processes of wider organizational system } \\
\text { - Turnover of response staff among stakeholders/ NGO partners } \\
\text { - } \quad \text { Response economy - "Ebola business" - payment of staff in context of } \\
\text { national wage and response wage }\end{array}$} \\
\hline
\end{tabular}

Figure 3 Cellulle d'Analyse en Sciences Sociales (CASS) logic model.

the quality of epidemiological and social sciences data collection tools and of the analyses conducted. An intermediate outcome of the establishment of the CASS is it seeks to better understand broader health dynamics influencing the Ebola outbreak and community health outcomes resulting from the outbreak. The CASS also created space for the integration and use of DHIS2 data on health services use and health outcome reports from healthcare facilities across the country on a monthly basis. This integration addresses the critical need to understand preoutbreak healthcare-seeking behaviours and health outcomes which take concurrently within an outbreak. For example, understanding the relationships between the free-healthcare policy applied during 
the Eastern DRC Ebola outbreak, increased healthcare services use and increased risks for nosocomial infection. The CASS and Epidemiological Cell facilitated systematic integrated outbreak analytics (IOA), which aims to understand and describe epidemiological findings through the social, environmental behavioural drivers and barriers that influence outbreak dynamics and the impacts of outbreaks on communities. During the stakeholder and modelling process, this approach was recognised as creating a richer understanding of the outbreak's dynamics and making both epidemiological and social sciences evidence more useful.

\section{WHERE IS CASS NOW?}

Since the end of the North Kivu outbreak, the CASS has been active in four events: three in the DRC (Ebola in Equateur province, cholera and COVID-19) and one in Guinea (Ebola). These experiences demonstrate the transferability of the model and its potential for expansion to respond to different disease scenarios. CASS's response to the Equateur Ebola outbreak (2020) was a natural extension of the support provided in the Eastern region. For this event, IOA as an approach to evidence generation was successful, with 86 new recommendations produced of which 58\% in November 2020 had been fully or partially applied). In the DRC, COVID-19 presented a new scenario for CASS response. CASS worked to bring in additional data sources to extend the integration of different perspectives, combining social, behavioural and health services analyses with epidemiological trends, markets and context analyses (political events and conflict). ${ }^{16} \mathrm{~A}$ key focus of CASS research has been on providing evidence of the negative impacts of COVID-19 Public Health and Social Measures on communities, notably focusing on the socioeconomic and sexual and reproductive health, nutrition and safety and security on women and girls, and aiming to influence and change response strategies. ${ }^{17}$ The adaptation has, however, presented its own challenges, in part, due to the scale of the needs (eg, the impact of the increase of the exchange has had on communities which cannot be addressed at the local level), the dispersion of the disease and the prioritisation of limited funds for the biomedical response excluding the assessment of socioeconomic impacts of COVID-19 on populations. The DRC CASS continues to have the support of the $\mathrm{MoH}$ and has hosted workshops supported by the MoH COVID-19 leadership to bring together different actors to understand the impacts of COVID-19 and identify opportunities to mitigate them. CASS teams have continued to provide routine support via presentations and coaching on the use of key study results, lessons learnt and supported strategies to replicate similar approaches both at a global and regional level. In the DRC, the CASS has started setting up IOA for cholera outbreak response in the East.

The 2021 Guinea Ebola outbreak provided opportunity for the CASS model to be replicated in an integrated way from the outset. An IOA cell was set up, supported by the same partners and experts with the DRC experience. Based on the success of the DRC model, the cell structure (ToR) was rapidly approved and integrated into the $\mathrm{MoH}$ coordination and response within weeks of the outbreak, and integrated analyses to support the response were presented from immediately thereafter. The $\mathrm{MoH}$ and the Agence Nationale de Sécurité sanitaire in Guinea led and WHO, UNICEF, CDC, IFRC and MSFEpicentre, including specific deployments supported via DRC CASS leadership, staffed the cell. With support of Global Outbreak Alert and Response Network and other partnerships, mechanisms are being identified to replicate similar structures for future outbreaks.

\section{CONCLUSIONS}

In this paper, we describe the CASS as a successfully applied good practice service for integrated, operational analytics in outbreak response. A wide range of stakeholders consulted in the development of this work recognised CASS practices and technical guidance as innovative and successful in changing the way analytics are conducted and used in outbreaks.

The CASS model evolved organically in response to a critical gap in understanding of outbreak dynamics in an integrated way as well as to a need to bring outbreak response actors together for improved use of evidence in decision-making. Its success requires availability or capacity to collect data from different sources, buy-in from leadership, response teams working towards a common goal and a collaborative ethos of partners interested in an evidence-based approach to outbreak response. Uptake and effective use of evidence to inform response actions remains a challenge. The documentation of all tools, training materials as well as question banks, lessons learnt and hands on available support from CASS teams has been made available to actors working in outbreak response. In this way, others can access the CASS model and ways of working and adapt it for different contexts and outbreak scenarios, to generate and use integrated outbreak analytics for more effective response to public health emergencies.

\footnotetext{
Author affiliations

${ }^{1}$ Public Health Emergencies, UNICEF, New York, New York, USA

${ }^{2}$ Institut National de Recherche Biomédicale, Kinshasa, The Democratic Republic of the Congo

${ }^{3}$ Public Health, Prince Leopold Institute of Tropical Medicine, Antwerpen, Belgium ${ }^{4}$ Epicentre, Paris, France

${ }^{5}$ Centre for Mathematical Modelling of Infectious Diseases, London School of Hygiene \& Tropical Medicine Faculty of Epidemiology and Public Health, London, UK ${ }^{6}$ Health Emergencies Programme, World Health Organization, Geneve, Switzerland ${ }^{7}$ London School of Hygiene \& Tropical Medicine, London, UK

${ }^{8}$ Ministry of Health, Kinshasa, The Democratic Republic of the Congo

${ }^{9}$ National Center for Emerging \& Zoonotic Infectious Diseases, Centers for Disease Control and Prevention, Atlanta, Georgia, USA

${ }^{10}$ UNICEF, Brazzaville, The Democratic Republic of the Congo

${ }^{11}$ Dakar Hub, World Health Organization Regional Office for Africa, Dakar, Senegal

${ }^{12}$ University of $\mathrm{Xxford}$, Oxford, UK
} 
Twitter Simone E Carter @simone_tweets, Sophie Meakin @SophieMeakin and Julienne Ngoundoung Anoko @AnokoJulienne

Collaborators Pia Huq; Isabel Scott Moncrieff; Francklin Soung Iballa Brice; Sonya Sagan; Emilie Buttarelli; Philomene Mwanza Palaku; Jessica Petz.

Contributors SEC set up and managed the CASS and developed and drafted the manuscript and logic model. SA-M oversaw the coordination and integration of the CASS and the Epidemiological Cell to inform response interventions and reviewed and contributed to manuscript. JPZ, CNC and CU worked as part of the UNICEF response leadership to support the CASS. They further reviewed and contributed to the manuscript revision. EVK, OIPdW, SM, PL and TJ all contributed to the in-country application of integration of CASS and Epidemiological Cell. They contributed to the manuscript review and revision. MM and DBN supervised and supported the integrated CASS and Epidemiological cells, both reviewed and revised manuscript. M-AD provided remote support to the Epidemiological Cell throughout the outbreak and contributed to manuscript review. GE-R supported remote data analysis for the CASS during the DRC Ebola outbreak and contributed to manuscript review and revision. ME contributed to the drafting of the manuscript. JNA collaborated with the CASS during the Ebola response and contributed to manuscript review. NG identified the funding for the consultation process and work described in the paper and led the consultation process to model and replicate the CASS in future outbreaks. She developed the logic model, contributed to draft and all revisions of the manuscript.

Funding This study was funded by Wellcome Trust (BZR02530) and Foreign, Commonwealth and Development Office (BZR02530).

Competing interests None declared.

Patient consent for publication Not required

Provenance and peer review Not commissioned; externally peer reviewed.

Data availability statement Data are available in a public, open access repository.

Supplemental material This content has been supplied by the author(s). It has not been vetted by BMJ Publishing Group Limited (BMJ) and may not have been peer-reviewed. Any opinions or recommendations discussed are solely those of the author(s) and are not endorsed by BMJ. BMJ disclaims all liability and responsibility arising from any reliance placed on the content. Where the content includes any translated material, BMJ does not warrant the accuracy and reliability of the translations (including but not limited to local regulations, clinical guidelines, terminology, drug names and drug dosages), and is not responsible for any error and/or omissions arising from translation and adaptation or otherwise.

Open access This is an open access article distributed in accordance with the Creative Commons Attribution Non Commercial (CC BY-NC 4.0) license, which permits others to distribute, remix, adapt, build upon this work non-commercially, and license their derivative works on different terms, provided the original work is properly cited, appropriate credit is given, any changes made indicated, and the use is non-commercial. See: http://creativecommons.org/licenses/by-nc/4.0/.

\section{ORCID iDs}

Simone E Carter http://orcid.org/0000-0003-3818-3538

Sophie Meakin http://orcid.org/0000-0002-6385-2652

\section{REFERENCES}

1 Rohan H, McKay G. The Ebola outbreak in the Democratic Republic of the Congo: why there is no 'silver bullet'. Nat Immunol 2020:21:591-4.

2 World Health Organization. Ebola outbreak 2018-2020- North Kivu/ Ituri, DRC. Available: https://www.who.int/emergencies/situations/ Ebola-2019-drc- [Accessed 20 Jun 2021].

3 Nachega JB, Mbala-Kingebeni P, Otshudiema J, et al. The colliding epidemics of COVID-19, Ebola, and measles in the Democratic Republic of the Congo. Lancet Glob Health 2020;8:e991-2.

4 Roberts L. Polio outbreaks in the DRC threaten eradication effort. Science 2018;361:10-11.

5 Social science in humanitarian action. key considerations: the context of North Kivu Province, DRC, Aug 2018:1-8. Available: https://opendocs.ids.ac.uk/opendocs/bitstream/handle/20.500. $12413 / 13995 /$ SSHAP North Kivu_context.pdf? sequence $=18$ isAllowed $=y$

6 Sweet R, Bedford J, Gercama I. Politics, factions and violence: listening to local voices on Ebola, 2019. Local media update \#3 (Feb-Apr 2019). Available: https://opendocs.ids.ac.uk/opendocs/ bitstream/handle/20.500.12413/14497/SSHAP Local and social media_brief_3_February_April_2019.pdf\%0Ahttps://www.cabdirect. org/cabdirect/abstract/20193525334

7 Polonsky JA, Baidjoe A, Kamvar ZN, et al. Outbreak analytics: a developing data science for Informing the response to emerging pathogens. Philos Trans R Soc Lond B Biol Sci 2019;374:374:20180276.

8 Cori A, Donnelly CA, Dorigatti I, et al. Key data for outbreak evaluation: building on the Ebola experience. Philos Trans $R$ Soc Lond B Biol Sci 2017;372:372:20160371.

9 Bardosh KL, de Vries DH, Abramowitz S. Integrating the social sciences in epidemic preparedness and response: a strategic framework to strengthen capacities and improve global health security. Global Health 2020;16:1-18.

10 Social Sciences Analytics Cell (CASS). Social science support for COVID-19: briefings from the Cellule d'Analyse en Sciences Sociales, 2020. Social science in humanitarian action platform. Available: https://www.socialscienceinaction.org/blogs-and-news/ social-science-support-covid-19-briefings-cellule-danalyse-ensciences-sociales/ [Accessed 18 Jun 2021].

11 Social Sciences Analytics Cell (CASS). Tor integrated analytics cell - Google drive, 2020. Available: https://drive.google.com/drive/ folders/1Rapw2LqVIwCIB_XfgUWvPbwmo_JSLnnl [Accessed 18 Jun 2021].

12 World Health Organization. Ebola virus disease outbreak, guinea: Multi-country strategic readiness and response plan, 2021. Available: https://www.who.int/publications/m/item/ebola-guineamulti-country-strategic-readiness-and-response-plan [Accessed 18 Jun 2021].

13 Ministry of Health (DRC). Strategic response plan for the Ebola virus disease outbreak in the provinces of North Kivu and Ituri, Democratic Republic of Congo, 2019

14 Dewulf A, Ciza AM, Irenge L. Collective approaches to risk communication and community engagement in the Ebola response in North Kivu, Democratic Republic of Congo, 2020

15 Social Sciences Analytics Cell (CASS). Documentations sur les recommendations, 2020

16 Carter SE, Gobat N, Pfaffmann Zambruni J, et al. What questions we should be asking about COVID-19 in humanitarian settings: perspectives from the social sciences analysis cell in the Democratic Republic of the Congo. BMJ Glob Health 2020;5:e003607.

17 Social Sciences Analytics Cell (CASS). The impacts of the COVID-19 outbreak response on women and girls in the Democratic Republic of the Congo, 2020

18 Social Sciences Analytics Cell (CASS). Perceptions des risques des femmes (enceintes \& allaitantes) et enfants - Google Drive, 2018 Available: https://drive.google.com/drive/folders/1UN854nB40x7 URPYQQXOgr3PxzFRzIYSp [Accessed cited 2021 Jun 20].

19 Social Sciences Analytics Cell (CASS). Perceptions et comportements Du personnel de santé- Google drive, 2019. Available: https://drive.google.com/drive/folders/1bxV9PUV15qS eLFI8WCciy8LRPaJACJfG [Accessed 20 Jun 2021].

20 Social Sciences Analytics Cell (CASS). Perceptions et utilisation des services de santé en fonction de l'évolution de l'épidémie et des interventions de la riposte, 2019. Available: https://drive.google.com/ drive/folders/1xTvyE-VFFuiv4hXjrnKAgdA25j8tP1sU [Accessed 20 Jun 2021].

21 Social Sciences Analytics Cell (CASS). Présentations EOC - Google drive, 2020. Available: https://drive.google.com/drive/folders/1hfm rFe5KgVeqloEsT2QQ-RKOLf_COtgn [Accessed 21 Jun 2021].

22 Social Sciences Analytics Cell (CASS). Perception des risques d'infection de la MVE chez les enfants - Google Drive, 2020. Available: https://drive.google.com/drive/folders/1II5e5unktQsU-ZQTpZ4R7g-hA6Tcdw [Accessed 20 Jun 2021].

23 Social Sciences Analytics Cell (CASS). Eastern DRC EBOLA studiesfull list and access to ressources 2018-20.xIsx - Google Drive, 2020. Available: https://drive.google.com/file/d/1C4zDhNHID-lgfdA5me omxWeKmdJtIKGw/view [Accessed 21 Jun 2021]. 